\title{
A MODEL FOR AN INLAND PORT IN AUSTRALIA
}

\author{
K.T.K. TOH \\ R. OAKDEN \\ P. NAGEL \\ C. SENGPIEHL \\ P. SHI \\ keith.toh@vu.edu.au \\ Institute for Logistics and Supply Chain Management, \\ Victoria University, Melbourne, Australia
}

\begin{abstract}
This paper examines the role of an inland port particular to the outer regions of Melbourne, Australia. In this study, it has been experienced that the broad use of terminology, in the Melbourne context, has been a stumbling block. In its particular context, this has provided the impetus for the development of a model for an inland port that is unambiguous. It is clear from international examples that such a development acts as a significant potential nucleus for regional economic growth, but the lack of a facilitated discussion is an impediment. This model is offered as a facilitator and a useful tool in the construction of a common understanding.
\end{abstract}

\section{INTRODUCTION}

This paper describes a model for an inland port in Australia. It follows a project carried out by the Institute for Logistics and Supply Chain Management (ILSCM), which researched and proposed a strategy to transform the western region of Melbourne's current strengths in transport and distribution. Clearly, to be economically strong, a region needs to have an integrated mix of manufacturing, logistics services, business services, retail and education with associated government services and administration. The conceptual structure of an inland port is offered as a means to facilitate a common concept and understanding of inland ports. This approach has been used as there is a tendency for inland ports to be considered synonymous with intermodal hubs, or intermodal terminals, which represents an undervaluation of the potential to support greater regional economic growth and sustainability.

The model captures the core services and what distinguishes an inland port. It subsequently includes other concepts such as technology precincts, and crucial ancillary services such as financial and legal services that may be associated in proximity to the precincts of the inland port. 


\section{LITERATURE REVIEW}

Increasing terminal throughput and therefore productivity has become a challenge for many container ports, particularly in light of larger container ships placing pressures on port operations. Improvement of throughput involves the purchase of more efficient intermodal equipment and potentially the expansion of terminal facilities. In many cases, lateral expansion may not be an option because bottlenecks are consequently created at the gate and local access routes due to the amount of truck traffic servicing the terminal (Woxenius et al. 2004). A better sea transport-seaport terminal interface in combination with the efficient integration of the seaport terminal-hinterland interface appears to be an important step in the improvement of the throughput, speed and efficiency of port terminals.

The "agile port" links on-dock rail facilities directly through a dedicated rail corridor to a nearby inland rail terminal where containers can be sorted by destination. This is to reduce container dwell time at port terminals and increase their throughput capacity (The Tioga Group 2006). The core of the concept is rail transfer of unsorted containers from vessel to an inland point where sorting takes place (Bryan et al. 2006). The agile port concept trades off additional cost (handling) and inland space for increased port throughput (SCAG 2006).

Some freight movements may use and justify the use of different transport modes, such as road, rail, inland waterway and either short or deep-sea shipping, thus making the port one of multimodal operations. An intermodal hub is the configuration of physical operational entities which facilitates the movement of goods shipment using multimodal transport units. Transport units are trucks, trains, barges, short sea and deep sea vessels.

Intermodal freight transport utilises two or more "suitable" modes of transport, in combination, to form an integrated transport chain aimed at achieving operationally efficient and cost-effective delivery of goods in an environmentally sustainable manner from their point of origin to their final destination (Lowe 2005). Bontekoning et al. (2004) noted the lack of a consensus definition and a common conceptual model for intermodal freight transport. Related to this, Bichou and Gray (2005) noted that academic literature is limited in conceptualising the various multi-faceted and complex aspects of port operations and management. Intermodal freight transport was identified by Transport Canada (2004) as one of its key policy priorities.

In the context of the state of Victoria, considerable challenges remain where the tendency for ad hoc growth has resulted in dispersion of logistics facilities and operations across the state. Intermodal hubs already play a crucial role in the state of Victoria and Figure 1 provides an indication of the facilities operating in the region. The contribution of the logistics industry to Victoria's economy is significant and the volume of freight continually grows (DIIRD, 2007). 


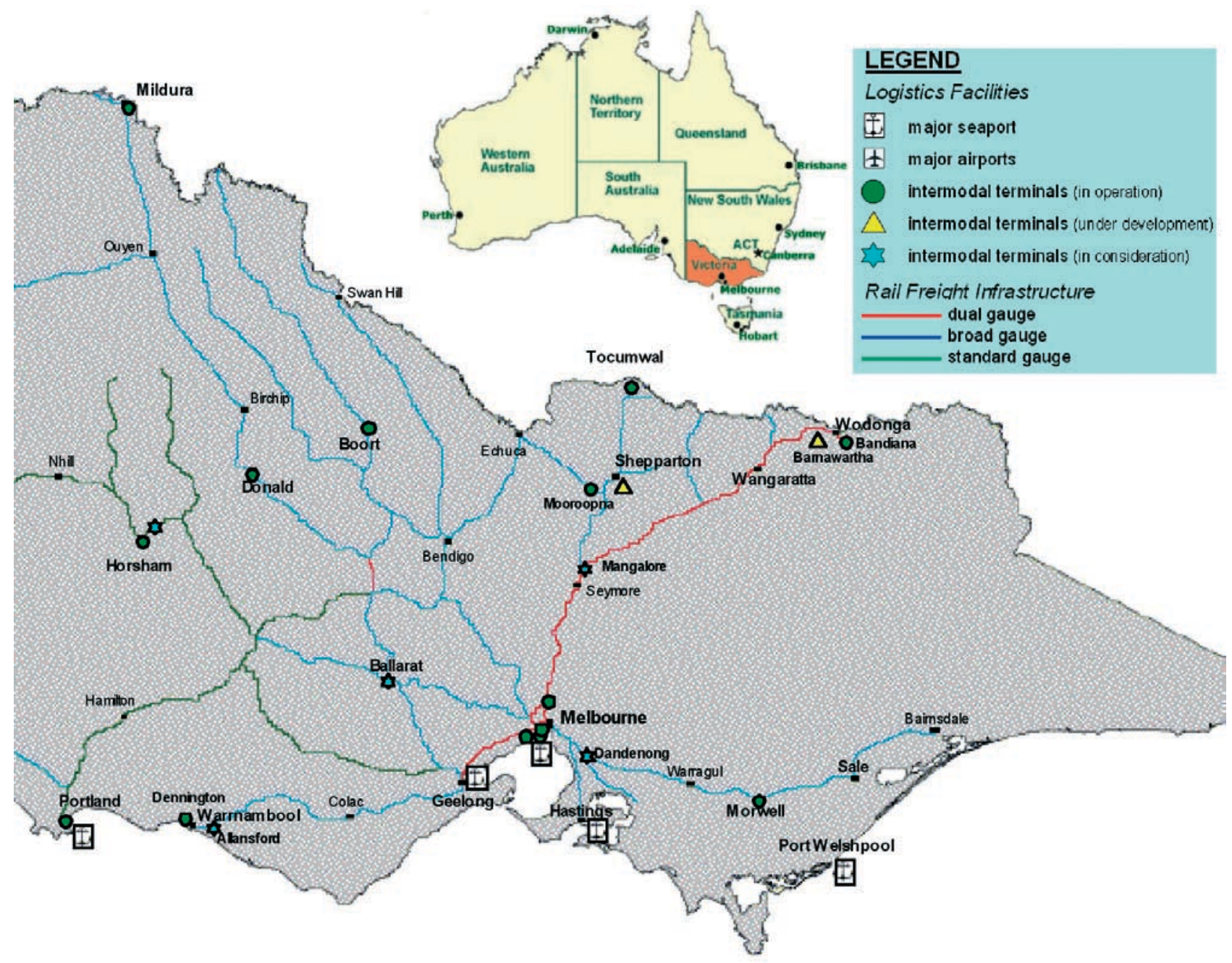

Figure 1: Geographical dispersion of logistics in Victoria

The Victorian government has a rail target for port cargo of 30\% by 2010 (Auslink 2007). The means to achieve the government's port-related rail target is to focus on attracting the more than one million TEUs bound for, or originating from, areas of freight activity within metropolitan Melbourne. While this relies on a functioning network of freight terminals capable of offering port rail shuttle services in a reliable, consistent and cost-competitive manner, ILSCM's research indicates that far-reaching benefits for the regional economy must include the development of intensive trade activity around a "nucleus" freight hub, and an inland port offers such potential.

Several definitions, along with feasibility studies, exist for an inland port, namely those given by Walter and Poist (2004), Leitner and Harrison (2001), Semoon and Canode (2003), Cumming and Elzer (2007) and Cambridge Systematics (2007). Harrison et al. (2004) noted the difficulty in classifying the wide variety of inland ports identified throughout the world. Essentially, it is a site or nodal point containing multimodal transport assets that are located away from traditional land, air and coastal borders (Jaržemskis \& Vasiliauskas, 2007). These assets and accompanying logistics services as well as value-added services facilitate and process international and domestic trade as goods move through the supply chain. 
An inland port is a port facility on an inland waterway or an inland site performing several functions of a seaport. An inland port does not necessarily require a waterway or a link to maritime transport, depending on geographical circumstances (Bichou \& Gray, 2005). It is believed by authors that inland ports have the capability to create local employment, enhance corridor efficiencies and thus trade competitiveness, at reduced public and private costs (Prozzi et al., 2002; Dooms \& Macharis, 2003). Walter and Poist (2003) recommend that implementation of a regional inland port commences with an emphasis on information technology and services rather than capital-intensive physical assets. There is also the consideration of potential free trade zone benefits and attraction of manufacturing and agglomeration economies (Head et al., 1999; United Nations, 2006; Mathur \& Mathur, 1997).

In the case of linking to a seaport, efficient distribution and environmental benefits are achieved by setting up the link through a high-capacity rail link (Roso, 2007). An economic premise is that the high-capacity or high efficiency rail connection must operate with a lower unit cost than the transport of containers by road. The containers are collected from the seaport and distributed to their ultimate destinations with the modal transfer between rail and road taking place at the inland site.

\section{MODELLING OF AN INLAND PORT}

There is an absence of a generally accepted conceptual model of an inland port. The review by Bontekoning et al. (2004) of the scientific knowledge base of literature in the field of intermodal freight transport listed 18 definitions applied in the literature covered. The purpose of their review was to summarise selected material which has been written on the issue of intermodal freight transport with a view to identifying: the key impediments and barriers to intermodalism; possible strategies to overcome these barriers and impediments; knowledge gaps; and steps for further research (Bontekoning et al., 2004).

Melbourne serves as the central distribution focus for this activity and handles $40 \%$ of the nation's container trade. However, in contrast to other major ports in the region, such as Dubai, Hong Kong and Singapore, which are transfer-oriented, Australian ports are destination ports. The characteristics, and therefore, the efficiencies will be different. Economic growth and activity has had consequences for the surrounding western region of Melbourne, which is experiencing adverse social and economic impacts. The following is a list of current issues:

- inefficiencies due to non-integrated business models

- increased road-based freight traffic through the ad hoc development and predominance of a non-integrated transport and storage sector in western Melbourne 
- lack of significant strategic transport demand intervention leading to high demand on road traffic infrastructure and congestion, and excessive transport demands for labour force access to inner and eastern Melbourne

- reductions in effectiveness and efficiency of transport infrastructure resulting in threats to the Victorian manufacturing and logistics sectors operating in, and with, the inner and outer western Melbourne municipalities

- continuing import of services from the central business district (CBD) and eastern region of Melbourne, thereby increasing cross-city traffic demands to the west.

One approach is to deliver significant improvement in efficiencies and cost savings, and allow industries to rapidly deploy innovation (coupled with effective risk management) in some consolidation of logistics-related infrastructure. The development of an inland port model is offered as the core of a hub-and-spoke approach to planning of business services near its physical precinct (see Figure 2).

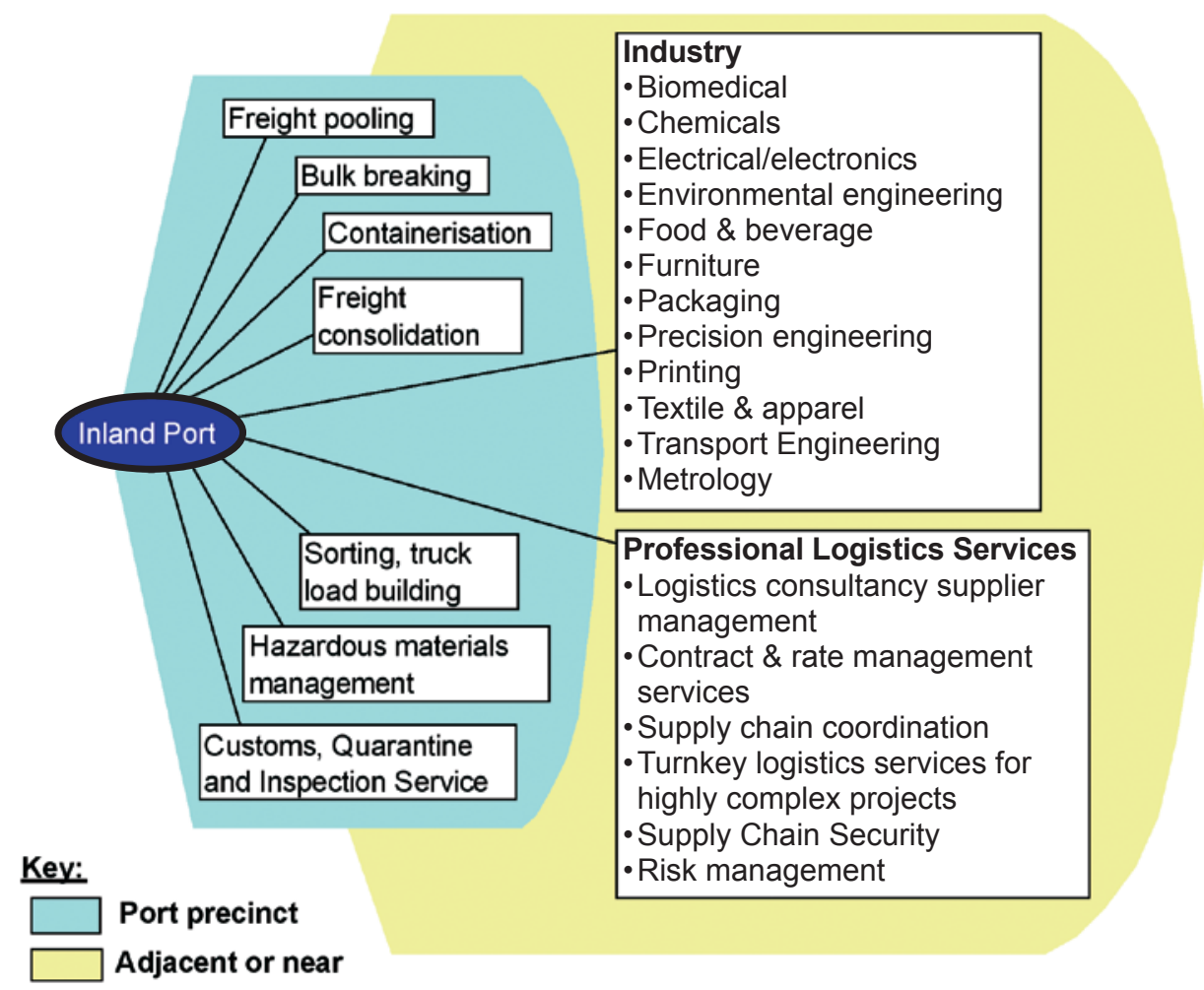

Figure 2: A hub-and-spoke view of the services

The overall development of a central or "nucleus" inland port model provides a view of the core services in the port, and what businesses and industry need to be attracted near its precincts. For example, while the port precinct may be government-owned, the surrounding areas may be controlled through statutory planning (e.g. industrial zoning) and adequate buffers may be enforced. Adjacent to or near the precinct, an industrial base consisting of a varied and effective tenant mix must be promoted through effective relationships that include government, private sector development and potential users. Buffer zones are used to protect the urban environment. 
The presence of a customs facility is one of the distinguishing features of an international inland port. More specifically, an international inland port is the intended port of discharge or final destination stated in the bill of lading. To address the tendency for intermodal hubs to be referred to as inland ports, a model has been developed and is shown in Figure 3 .

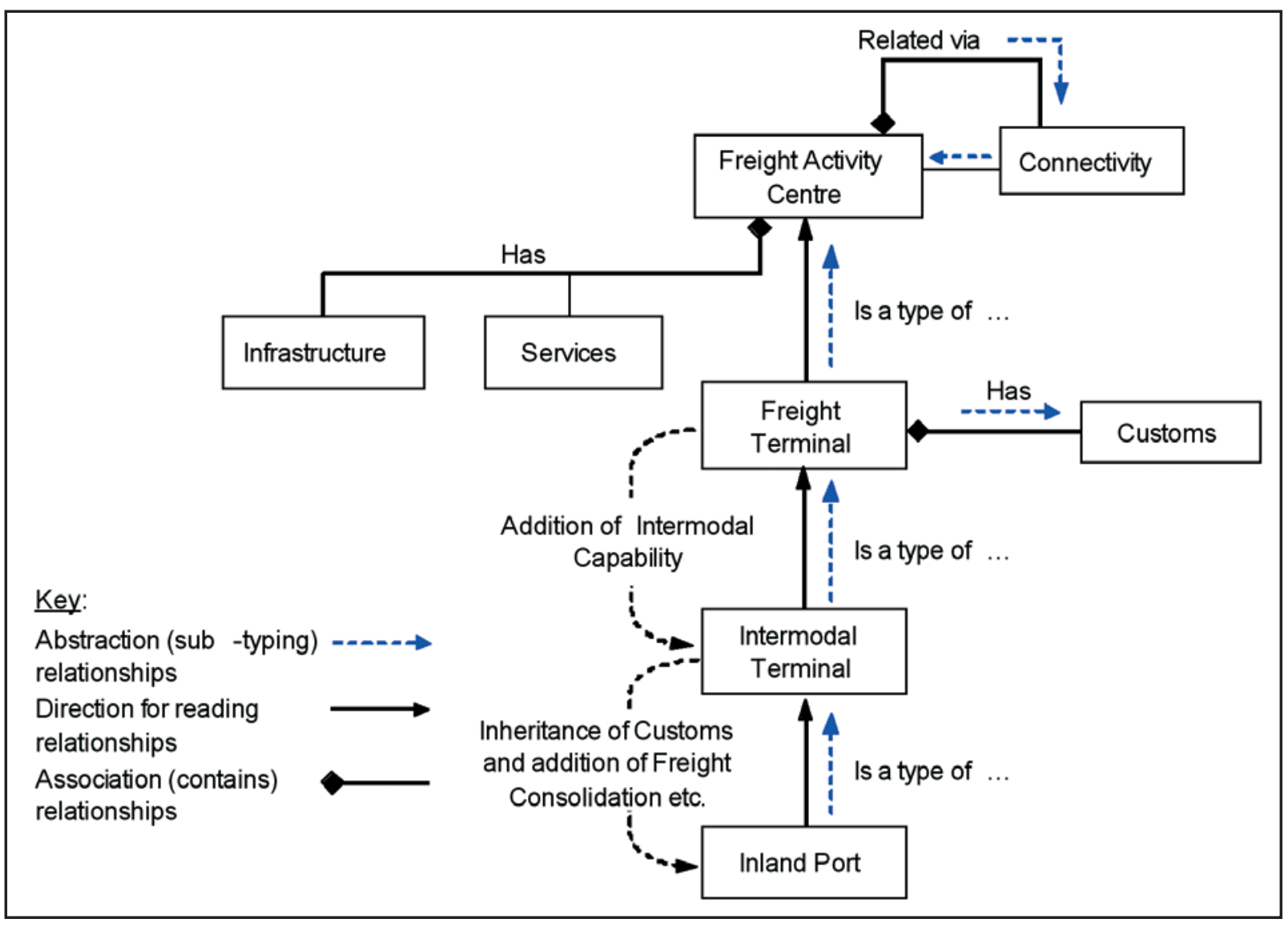

Figure 3: The "genre" of an inland port

This model has been used to communicate the distinguishing features of an inland port. In this case, the inland port inherits the intermodal capability, but it has added capability in terms of its customs-related functions. The "freight activity centre" as a more abstract concept has been encountered. By allocating infrastructure and services as modelling elements at the "parent" level of a freight activity centre, all child instances (such as freight terminals, intermodal terminals, etc.) inherit these constructs. This avoids repetition in the model. An inland port incorporates intermodal transport; this facility complements other gateway ports such as major seaports and airports that have the potential to expand or extend capabilities of these gateways. Hence the inland port is located in rural settings where land costs and land uses are less restrictive, close to key markets and have efficient access to the gateways.

As indicated in Figure 3, there is an addition of intermodal capability to provide a diverse and effective transport mix (comprising both high capacity rail and road). One important feature for an inland port in this context is the provision of a customs processing centre to 
enable faster throughput of goods at inland gateway ports to relieve the existing pressure of restricted capacity. The model of an inland port, presented in this manner, provides an explicit representation which has the capability of showing inheritance relationships. In the model, the freight activity centre and freight terminals are all stages in a progression leading to an inland port.

In addition to the services view (illustrated previously in Figure 2), the model also requires an infrastructure view (Figure 4).
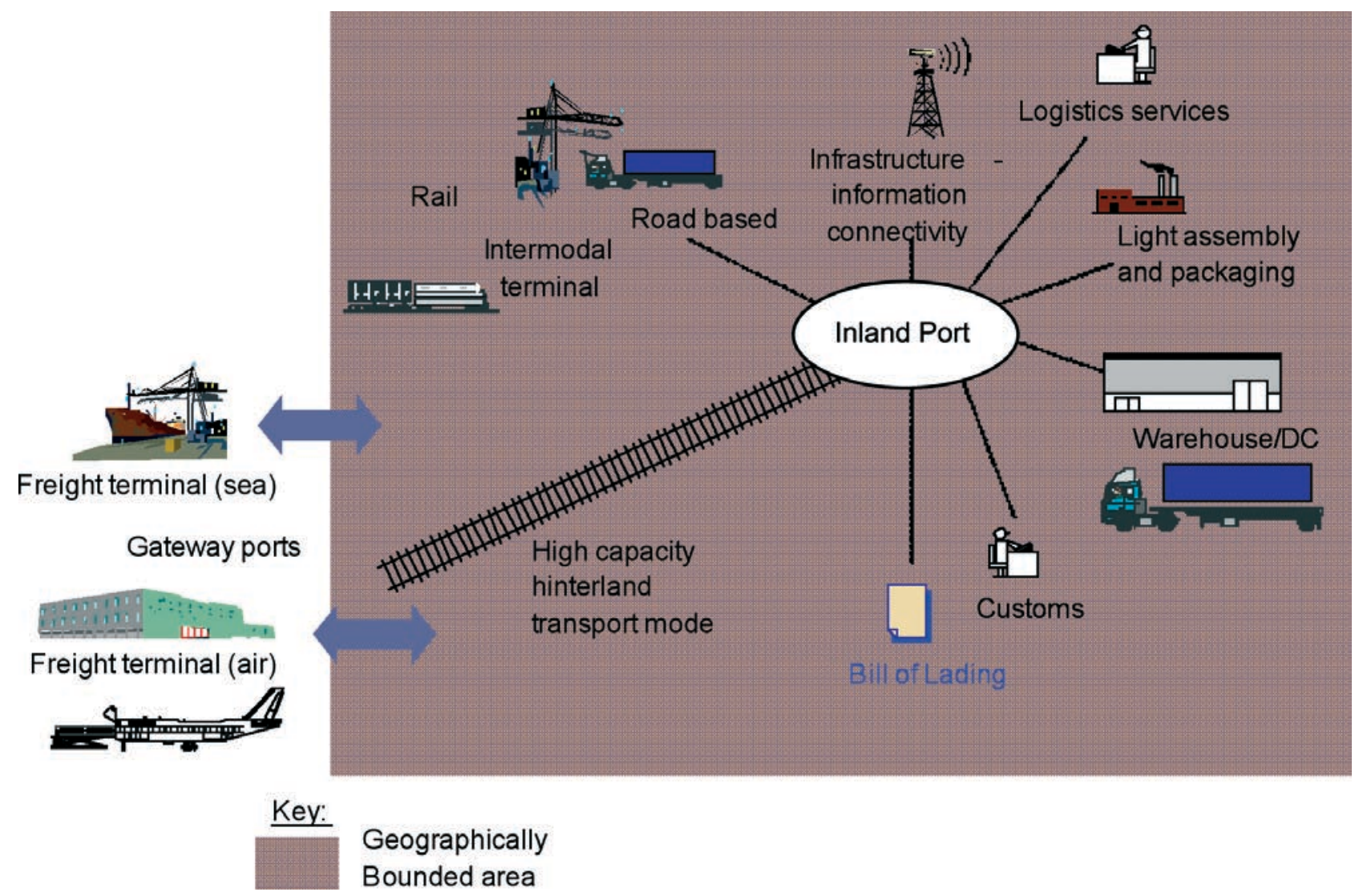

Figure 4: Schematic of an inland port - infrastructure components

As a remote international trade processing facility, an inland port provides goods movement outside of the normal boundaries of Melbourne's seaport. The proposal for an inland port is to extend the seaport to an inland location by providing an inland facility with a high capacity hinterland transport mode to facilitate cargo movement on a frequent basis between ocean-going vessels at the main port and the intermodal transfer site.

Through the relocation of truck and rail distribution facilities away from the main port site, an inland port facility can reduce congestion from truck traffic in the area of the main port and removes constraints on port expansion that are attributable to truck capacity limitations (Bryan et al. 2006). Examples include the Virginia inland port (VIP), the European Container Terminal (ECT) in The Netherlands, Nilai inland port (NIP) in Malaysia, and New York's Port Inland Distribution Network (PIDN). 
The model in Figure 3 shows that the inland port is a derivative of a freight activity centre with infrastructure and service components. The profile of infrastructure elements are well known, but the profile of services in terms of compatible use include the information given in Table 1.

Table 1: Functional descriptor

Service profile that supports functionality beyond freight transition at an inland port

- Loading/unloading

- Freight consolidation (operations): consolidate freight which destinations are in close proximity to enjoy the economy and efficiency of scale

- Freight sorting: sort out the freight according to types, destinations or delivery times, etc., so that following consolidation or despatching operations can be carried out

- Truck load building, e.g. Less than Truck Load (LTL) management: to manage the LTL freight and try to maximise the utilisation of each truck trip

- Freight receipting: receipting the freight coming into the logistics terminal

- Last mile despatch: despatch freight that comes into the terminal to end customer/consumer

- Freight tracking: to provide information about the status and places of freight within the terminal

- Container management (storage, tracking, inventory management and repair): services related to storage, locating, inventory control, and repairing of empty containers

- Containerisation, bulk breaking

- Hazardous materials management
- Terminal congestion management: effective and efficient control of the traffic within the terminal

- Terminal management (HR, finances, payroll, administration)

- Real time traffic management, traffic analysis: provide information about the incoming and outgoing traffic flow to guide the future arrivals and departures of freight vehicles

- Freight (facility) operations, e.g. crane operations, berth operations, forklift, handling of freight vessel notifications

- One-stop shop coordination point for the ordering of pilot services, tugs, lines boats, lines men, quarantine services and customs.

\section{International port functionality}

- Customs, e.g.:

- Customs scan process

- Vessel notification

- Cargo declaration

- Transit declaration

- Border control

- Cargo declaration status report

- Duty/tariff payments

- Quarantine and inspection service (e.g., veterinary cargo declaration, veterinary inspection, cargo information, transit declaration). 


\section{Sustainability as a unique value proposition}

Further development of the model for an inland port close to Melbourne has been focused on achieving increased efficiencies of the dispersed logistics centres through a collaborative business model to bring about a value proposition of sustainable growth and environmental benefits (see Figure 5).

\begin{tabular}{|c|c|c|}
\hline People & $\begin{array}{l}\text { Efficient Services at Gateway Port } \\
\text { Minimal container dwell } \\
\text { Increased throughput } \\
\text { Logistics services } \\
\text { On time } \\
\text { Efficient transport utilisation } \\
\text { Reduced environmental impact } \\
\text { Reduced congestion }\end{array}$ & $\begin{array}{l}\text { Technology } \\
\text { Cutting edge } \\
\text { Business process enhancement } \\
\text { Reliable } \\
\text { Increased uptake } \\
\text { Interoperable }\end{array}$ \\
\hline $\begin{array}{l}\text { Employment opportunities } \\
\text { Improved conditions for trav }\end{array}$ & el to work & \\
\hline $\begin{array}{l}\text { Training opportunities } \\
\text { Alliances } \\
\text { Global industry leaders } \\
\text { Policies to facilitate trade } \\
\text { Government led "champion }\end{array}$ & $\begin{array}{c}\text { growth for } \\
\text { Melbourne's ou } \\
\text { regions }\end{array}$ & $\begin{array}{l}\text { Methodology } \\
\text { Business process change } \\
\text { Business process integration } \\
\text { Industry/government partnership } \\
\text { Business and technology architectures }\end{array}$ \\
\hline Economy & & Environment \\
\hline Attractive for new busines & investment & Reduced impact on environment \\
\hline Growth of professional busir & ness services & Reduced noise levels \\
\hline $\begin{array}{l}\text { Growth of trade } \\
\text { Lower unemployment }\end{array}$ & & Lower accident rate \\
\hline
\end{tabular}

Figure 5: A view of sustainability as a value proposition

While ILSCM's study was directed towards an historic legacy left by ad hoc growth in the western regions of Melbourne, future strategic development of the logistics industrial sector, as well as the other enabling industries, will provide an opportunity to ensure the sustainable growth of trade while taking measures to avoid an adverse impact on the environment and traffic congestion, due to increasing demand on the road infrastructure. This presents an opportunity to develop a plan for the transformation of a regional industrial base with integrated objectives including benefits to the economy as well as providing environmental and urban sustainability.

Design characteristics are important and the social, environmental and economic impacts are considerable. Of more importance is the lack of a common model which may lead to the under-promotion of such a facility.

An inland port must play a pivotal role in bringing about considerable benefits to the region. This value proposition must include improved communications that lead to better 
forecasting and planning of vehicle operations; in turn, vehicles are matched with more efficient loads. For urban sustainability, an adequate buffer is left between any of the inland port operations and residential neighbourhoods. The studies have indicated that the inland port must also feature integrated import-export facilities with Customs and the Australian Quarantine and Inspection Services. In consideration of environmental impact, the location is close to its customer base to minimise greenhouse gas emissions, fuel usage and turnaround times.

The inland port was first shown simplistically in Figure 3, but it provides the basis for communicating a higher level of functionality and intention, thereby providing the basis for thought leadership in these topics:

- virtual consolidation of the dispersed logistics facilities through business process and information integration

- a highly developed business and financial services sector away from the city financial district, thereby reducing travel into the city from outer suburbs

- growth of a supporting technology precinct to support or act as an "incubator" for businesses

- best practice agreements with gateway ports and transport networks

- the development of transit hubs with active retail precincts and excellent accessibility via train, bus and car. In the case of Melbourne, this also includes close proximity to the international airport

- sustainable residential areas with excellent amenities, which lessens the direct negative impacts of road traffic, but fosters urban environments which are more economically successful due to the greater social vitality possible in a city's public spaces

- labour sustainability in terms of the development of a highly skilled workforce through training and teaching

- valuable alliances with government agencies through the formation of a "champion agency or advocate" to promote the growth of a market that leverages off the international connectivity.

Of relevance to this paper and the development of lightweight "ontology" by the authors is the classification of services and infrastructure as two major elements of an inland port which is "customs controlled", having an association with a bill of lading as a transaction artefact. This results in a model which may be used to facilitate a variety of model-based studies through simulation. The approach is to develop this ontology as a re-usable design pattern through a catalogue of components with established relationships; due to constraints on the length of this paper, the ontology will be presented in future publications.

Through its studies, ILSCM has identified that industry cannot achieve a sustainable hub network without a proper framework of government policy settings, strategic plans and 
regulation being in place to secure investment around the core inland port infrastructure. The challenge to government is to provide the governance framework in order to facilitate public commitment and additional investment in infrastructure capacity on which businesses can build to service the freight task.

The Singapore Economic Review Committee (ERC) Working Group on Logistics reported that the transport and logistics industry offers great potential (Yeo, 2003) and based on this, the ERC Working Group proposed the idea of a champion agency to coordinate the government's efforts and act as a one-stop destination for the industry. This champion agency would play four roles - strategic; promotional; developmental and operational. The recommendation was for the champion agency to concentrate on promoting the transport and logistics industry in Singapore. The concept of a "champion agency" is heavily deployed in Singapore (ERC Working Group, 2002).

\section{Governance}

The pursuit of an integrated freight hub will require an immense amount of coordination, effort and work from the various sub-sectors of industry clusters and government agencies. A similar champion agency is required for Victoria to work with industry in identifying business and regulatory impediments which hinder the advancement of this region within Australia. The Singapore example states, that to be effective, the champion agency must possess four attributes, namely "clout", "mandate", "resources" and "deliverables" (ERC Working Group, 2002).

The development of a strategically located inland port can bring considerable benefits. This programme focuses on gaining economic and social benefits through the better integration of logistics services, infrastructure and assets of the regions within Melbourne. This is also done in conjunction with the Transit Cities initiative, which is part of the Melbourne 2030 strategy. Transit Cities is a major Victorian government programme to help revitalise metropolitan and regional centres to make them economically stronger and better places in which to live and work.

Within this context, it is necessary to develop the concept of an inland port based on sound understanding of its features and maximise the potential for economic growth to Australia, such as:

- more sustainable urban community

- consideration of potential free trade zone benefits, i.e. tax postponement, import-export benefits, etc. in order to grow a high-value-added industry

- secondary benefits, e.g. reduce traffic congestion and add capacity to the seaport. 
This also considers incompatible use, such as:

- storage of empty containers

- uncontrolled public use (retail, car rental)

- heavy manufacturing

- call-centres, help desks, etc.

\section{CONCLUSIONS}

The establishment of an inland port in western/north-western Melbourne is a tangible development option as it provides the nucleus for the integrated development of the region. The purpose of this paper is to present the inland port model elements in an unambiguous manner.

This model was put forward in order to facilitate an urgent need, which is to capture the opportunity to lead an innovative approach of treating the logistics facilities in the western/ north-western regions as being beyond just resources and to develop infrastructure and service profiles that are based on principles of integration and sustainability. By establishing and overcoming the terminology issues, it encourages broader consideration of the economic growth surrounding the logistics infrastructure.

Existing international examples have demonstrated that excellence in logistics services may be achieved with the application of information technology infrastructure that is required to facilitate the efficient movement of goods. Planning for an inland port includes telecommunications networks and information service providers that can readily meet the needs of the international trade and transport community. It was important for stakeholders to focus the planning beyond intermodal terminals.

In relation to this, a government champion agency must be formed that has the willingness to aggressively market the inland port concept locally, nationally and internationally, to gain community support and attract potential relocation prospects. This process must also be facilitated through a model that fosters common understanding.

Countries of Asia as Hong Kong, Taiwan, Malaysia, Thailand, Philippines and Singapore are positioning themselves to be logistics hubs of their surrounding regions. Of note, as a logistics hub, Singapore provides a comprehensive range of "soft" services ancillary to the physical handling of cargo (iGov, 2004; IDA, 2004). Although not geographically situated to have hubs, Australia may look to nations that possess world class connectivity and excellent physical, IT and financial infrastructure. 


\section{REFERENCES}

AusLink. 2007. Melbourne Urban Corridor Strategy, Auslink. Available from:

http://www.auslink.gov.au/publications/reports/pdf/melbourne_urban_corridor_strategy. pdf

Bichou, K. and R. Gray, R. 2005. A critical review of conventional terminology for classifying seaports. Transportation Research Part A: Policy and Practice, Volume 39, Issue 1, pp. 75-92.

Bontekoning, Y.M., Macharis, C. and Trip, J.J. 2004. Is a new applied transportation research field emerging?-A review of intermodal rail-truck freight transport literature. Transportation Research Part A: Policy and Practice, Volume 38, Issue 1, PP 1-34.

Bryan, J., Weisbrod, G. and Martland, C.D. 2006. Rail freight as a means of reducing roadway congestion: feasibility considerations for transportation planning. Transportation Research Record: Journal of the Transportation Research Board, pp 75-83, Issue 2008. Available from: http://www.ctr.ra.utk.edu/LRRFT/cmte_activities/papers/TRBAM\%2007-Bryan-WeisbrodMartland.pdf

Cambridge Systematics, Inc. 2007. South Florida inland port feasibility study, prepared for Florida Department of Transportation, Seaport Office by Cambridge Systematics, Inc., Available from: http://www.edri-research.org/clientuploads/Library/studies/Draft_Final_ Inland_Port_Study_06_08_07.pdf

Cumming, V. and Elzer, D. 2007. PG inland port: First Nations Economic Opportunities. Phase 1 Report. 32 pages. Westcoast CED Consulting Ltd. Available from: http://www.nkdf.org/uploads/file/docs/PG_Inland_Port-Phase_1_Report.pdf

DIIRD. 2007. The 2007 Victorian Transport and Logistics Industry Report. Office of Business Innovation and Strategy, Department of Innovation, Industry and Regional Development, Victoria, Australia.

Dooms, M. and Macharis, C. 2003. A framework for sustainable port planning in inland ports: a multistakeholder approach. The 43rd European Congress of the Regional Science Association (ERSA) University of Jyväskylä, Finland. 27-30 August. European Regional Science Association Conference Papers. Available from: http://www.ersa.org/ersaconfs/ersa03/cdrom/papers/201.pdf

ERC Working Group. 2002. Report of the Working Group on Logistics - Developing Singapore into a Global Integrated Logistics Hub. International Enterprise Singapore, Lead 
Secretariat, ERC Working Group on Logistics (with inputs from EDB). Available from: http://app.mti.gov.sg/data/pages/507/doc/ERC_SVS_LOG_MainReport.pdf

Harrison, R., McCray, J.P. and Prozzi, J. 2004. Inland port transportation evaluation guide (CTR 4083-P4), Center for Transportation Research (CTR), University of Texas at Austin. Available from: http://www.utexas.edu/research/ctr/pdf_reports/4083_P4.pdf

Head, C.K., Ries, J.C. and Swenson, D.L. 1999. Attracting foreign manufacturing: Investment Promotion and Agglomeration. Regional Science and Urban Economics, Vol. 29, p.p. 197218.

IDA. 2004. IDA Online Media Release: Singapore Anchors its Status as Global Logistics Hub by Harnessing Information Technology. Available from:

http://www.ida.gov.sg/News\%20and\%20Events/20050713120130.aspx?getPagetype=20.

iGov. 2004. About the Integrated Trade and Logistics IT Platform. Available from: http:// www.igov.gov.sg/NR/rdonlyres/C8F242DE-6C0D-4D40-A7A7-D94B7D2F6A09/4408/ tradenet1.pdf

Jaržemskis, A. and Vasiliauskas, A.V. 2007. Research on Dry Port Concept as Intermodal Node. Transport, Vol. 22, No. 3, pp. 207-213.

Lowe D. 2005. Intermodal Freight Transport (Paperback), Butterworth-Heinemann, ISBN 0750659351.

Leitner, S.J. and Harrison, R. 2001 The Identification and Classification of inland ports. Austin, Texas: Centre of Transportation Research. 1. Available from: http://www.utexas.edu/ research/ctr/pdf_reports/4083_1.pdf

Mathur, L.K. and Mathur, I. 1997. The Effectiveness of the Foreign-Trade Zone as an Export Promotion Program: Policy Issues and Alternatives. Journal of Macromarketing, Vol. 17, No. 2, 20-31.

Prozzi, J. Henk, R. McCray, J. and Harrison, R. 2002. Inland ports: Planning Successful Developments. Project conducted in cooperation with the U.S. Department of Transportation, Federal Highway Administration and the Texas Department of Transportation. Available from: http://www.utexas.edu/research/ctr/pdf_reports/4083_2.pdf

Roso V. 2007. Evaluation of the dry port concept from an environmental perspective: A note. Transportation Research Part D: Transport and Environment, Elsevier B.V., Volume 12, Issue 7, pp. 523-527. 
SCAG. 2006. Southern California Association of Governments. SCAG inland port feasibility study. Presentation to the Goods Movement Task Force June 21, 2006.

Semoon, C. and Canode, S. 2003. Economic Impact of the Choctaw Point Intermodal Facility on the Mobile Area, CBER Research Report \#52, 31 pages. Available from: http:// www.asdd.com/pdf/ASDReport1.pdf

The TIOGA Group. 2006. Inland port feasibility study by The Tioga Group, Inc., Railroad Industries, Inc. and Meyer Mohaddes Associates. Available from:

http://www.scag.ca.gov/goodsmove/pdf/InlandPort_Smith0606.pdf

United Nations. 2006. Free trade zone and port hinterland development. Economic and Social Commission for Asia and the Pacific

Transport Canada, 2004, Literature Review on Intermodal Freight Transportation, Transport Canada. Available from:

http://www.tc.gc.ca/pol/en/report/research/tp14502e/tp14502e.pdf

Walter, C.K and Poist, F.R. 2004. North American inland port development: International vs domestic shipper preferences. International Journal of Physical Distribution and Logistics Management 34: 579-597.

Walter, C.K., Poist, R.F. 2003. Desired attributes of an inland port: shipper vs. carrier perspectives. Transportation Journal, Vol. 42, No. 5 (Fall 2003), pp. 42-55.

Woxenius, J., Roso, V., Lumsden, K. 2004. The dry port concept - connecting seaports with their hinterland by rail. In Proceedings of the First International Conference on Logistics Strategy for Ports. China: Dalian.

Yeo, C.T. 2003. Address by Mr Yeo Cheow Tong, Minister for Transport at the 32nd Anniversary Dinner and Dance of the Singapore Organisation of Seamen (SOS) and the 9th Anniversary Dinner and Dance of Seacare Co-operative Ltd, 10 October 2003, Suntec City Ballroom, Singapore. 